\title{
Sustainability Performance of Village Credit Institutions (LPD) in Buleleng Regency
}

\author{
Novi Budiasni ${ }^{1}{ }^{*}$, Sri Ayuni ${ }^{2}$, Wulan Sari Sanjaya ${ }^{3}$ \\ 1,2,3,Sekolah Tinggi Ilmu Ekonomi Satya Dharma, Singaraja
}

\section{A R T I C L E I N F O \\ Article history: \\ Received 17 August 2018 \\ Received in revised form \\ 20 September 2018 \\ Accepted 18 October 2018 \\ Available online 25 \\ November 2018}

Keywords:

Sustainability Performance, Non Financial Perspective, Financial Perspective, Social Perspective based on Tri

Hita Karana, Village Editing Institution (LPD)

\begin{abstract}
A B S T R A K
Measurement and Performance appraisal are the important component of the Village Credit Institution (LPD). The management can also use LPD performance measurement as a tool to evaluate its business performance. There is a weakness in performance measurement, namely performance measurement that only measures financial performance, but has not been able to fully describe the condition of LPD to non-financial performance. This research was explanatory with the form of causality between variables. The number of LPD to be sampled were 59 LPD. The data analysis technique used in this study was SEM-PLS. Based on the results of hypothesis testing showed that the performance of the non-financial perspective has a significant positive effect on the performance of the financial perspective of the LPD in Buleleng Regency. Second, the performance of non-financial perspectives has a significant positive effect on the performance of a social perspective based on Tri Hita Karana LPD in Buleleng Regency. The three financial perspective performance and non-financial perspective performance have a significant positive effect on the performance of a social perspective based on Tri Hita Karana LPD in Buleleng Regency.
\end{abstract}

\footnotetext{
* Corresponding author.

E-mail addresses: novibudiasni@yahoo.ac.id (Novi Budiasni)
} 


\section{Pendahuluan}

The development of LPD is increasing, because people see the benefits offered by the LPD is great. LPD is one of the financial institutions in Bali that is managed openly by the relevant village community in accordance with the awig-awig (customary rules) that apply (Juliartana, 2014). The LPD was initiated based on Governor's Decree No. 972 in 1984, then replaced by Bali Governor Regulation No. 11 of 2013. LPD functions as a means to channel the wealth of traditional villages in the form of money or securities to be able to improve the standard of living of traditional village communities in order to realize village development. The point is the birth of LPD in Bali is expected to be able to encourage economic development of traditional Balinese villagers through direct savings and effective capital distribution and create jobs (Budiasni, 2016).

The increase of financial institutions, both bank and non-bank, makes competition for financial institutions including LPD increasingly stringent. LPD must do extra to provide the best service so that customers continue to actively cooperate in building LPD. LPD managers must be able to see the needs of the community. The Regional Development Bank (BPD) along with the Bali Provincial Government must work together to guide LPD in terms of human resources, risk management, capital, operations, rules, as well as in the face of future market developments (Perbawa, 2014). Especially LPD coaching is related to the assessment and measurement of LPD performance.

Appraisal and measurement performance is an important component of LPD. Besides being used to assess the success of a company, performance measurement can also be used as a basis for determining the reward system in a company. The management can also use the company's performance measurement as a tool to evaluate its business performance. There is a weakness in performance measurement, namely performance measurement that only measures financial performance, but has not been able to fully describe the condition of LPD to non-financial performance. Financial perspectives are important, but not enough to evaluate and plan LPD business strategies. The preparation of good strategic planning requires a variety of perspectives, not just financial perspective, but also non-financial perspectives, such as: customers, internal business processes, learning and growth. This perspective needs to be integrated so as to provide a strong synergy to underlie the evaluation process and strategic planning.

Score Card (BSC) is an alternative that can be used by LPD to measure performance. Good performance in both financial and non-financial perspectives. BSC consists of 4 perspectives (financial and non-financial perspectives), namely financial perspective, customer perspective, internal business process perspective and learning and growth perspective. These four perspectives work together to produce strategic goals and realize the goals of the LPD.

In addition to the financial and non-financial perspectives, the Bali Governor's Regulation dated March 7, 2013, explained that the net profit of LPD at the end of the accounting year was around 20\% used for village development funds and $5 \%$ for social funds. The social fund reflects that the LPD should care about the social aspects, not just fixing on the financial and non-financial aspects. The social aspect in question is the implementation of the social responsibility program by the LPD. These demands are in accordance with current business practices that are not only focused on profit but also include social aspects of corporate social responsibility and accountability (Ghozali, 2007). In order to maintain the sustainability of LPD, it is important to pay attention to financial perspectives, consumer perspectives, internal business perspectives and the perspective of growth and learning of LPD to pay attention to the social aspects of corporate social responsibility.

The importance of social aspects, namely social responsibility in a business is also stated by Archie B. Carrol and Elkington (1997) in the form of a pyramid concept and is based on the concept of the Triple Bottom Line. In this concept there is a concept of philanthropic responsibility that emphasizes social care. Likewise with the Triple Bottom Line concept, about the principle of people who emphasize the care of others to improve human welfare (Budiasni, 2016).

Sustainability has the potential to affect a company's performance (Aggarwal, 2013: 1). Sustainable performance describes a company that seeks to ensure its continuity. Lako A (2011: 6) states, in order to grow sustainably, corporations must integrate business objectives with intact social and ecological goals.

Stakeholder theory shows that sustainable activities and performance increase the long-term value of the company by fulfilling corporate social responsibility, meeting the company's environmental obligations and improving the company's reputation (Clarkson et al., 2007). However, social responsibility activities, environmental responsibility and improving the reputation of the company have a greater risk of resource allocation. This risk also has implications for shareholder decisions. As stated earlier, steps to implement sustainable activities and performance are very important for the long-term sustainability of the company. 
The shift that occurred seems to have been understood by the Bali Provincial Government, so that a regulation was established which required LPDs in Bali to allocate an annual net profit of $20 \%$ for village development funds and $5 \%$ for social funds. The allocation is clearly stated in the Bali Provincial Regulation No. 8 of 2002 concerning LPD (Budiasni, 2016). The rules established are a reflection of the Government's efforts

Bali Province to implement stakeholder theory and efforts to achieve the LPD term goals in Bali.

LPD in Bali is unique. In its operations, LPD in Bali is thick with elements of local wisdom. One of them is the local wisdom of Tri Hita Karana. The concept of Tri Hita Karana comes from the culture of the people in Bali. Tri Hita Karana (three things to achieve life prosperity) is a philosophical pattern of harmony and a harmonious balance of relationships. LPD's operational situation adapted to local wisdom reflects the government's desire not only to advance the economy but also to preserve culture and art (local wisdom) in Bali. Adjustment of the operational system with Balinese local wisdom will automatically cause LPD work programs to be adjusted to the Tri Hita Karana concept. Similarly, the social responsibility work program (CSR) is based on Tri Hita Karana. This adjustment, aims to make LPD in Bali get support from the surrounding environment and have an impact on the sustainability of LPD.

Based on data, LPD in Buleleng Regency in 2016 were 169 units. However, as many as 38 units were declared to be unhealthy, 27 units of LPD were stalled, 3 new units were operating and 5 units were not reporting (bulelengkab.go.id, 2017). This condition illustrates that almost 44\% of LPD in Buleleng Regency (Bali) experience unfavorable conditions. Various studies have been conducted to examine the company's sustainability performance and its impact on company performance. Researchers have used various types of performance measures. Accounting-based measurements such as ROA, ROE, PBT, and others. Furthermore, market-based actions such as stock returns, stock prices, MVA, and so on. Various sizes for the company's continued performance have been used. However, the results are not convincing, inconsistent, and often contradictory. This ranges from positive (Ngwakwe, 2009; Greenwald, 2010; Guindry \& Patten, 2010; Schadewitz \& Niskala, 2010; Eccles et al., 2012; N. Burhan \& Rahmanti, 2012; Khaveh et al., 2012; De Klerk \& de Villiers, 2012; Ameer \& Othman, 2012;) to be negative (Lopez et al., 2007; Detre \& Gunderson, 2011) to be mixed (Jones, 2005; Brammer et (Van de Velde et al., 2005; Buys et al., 2011; Adams et al., 2012; Venanzi, 2012; Humphrey et al., 2012).

Armed with the condition of LPD in Buleleng Regency which almost 44\% experienced poor conditions, and the results of previous contradictory research, the researchers intend to conduct a review of the ongoing performance of LPD in Buleleng Regency. The purpose of this study: 1) To determine the effect of non-financial perspective on the performance of financial perspectives, 2) to determine the effect of non-financial perspectives on the performance of social perspectives, and 3) to determine the effect of financial perspective performance and non-financial perspective performance on social perspective performance.

\section{Metode}

This research was conducted at LPD located in Buleleng Regency. In the early stages researchers will conduct research data collection. Research data will be collected by documentation and questionnaire methods. Documentation method for collecting financial report data which is then analyzed related to the performance of the LPD financial perspective. Furthermore, the questionnaire instrument will be distributed to LPD in Buleleng Regency.

This research is exploratory in causality between variables. The causality relationship studied in this study is between the performance of a non-financial perspective, the performance of a financial perspective and the performance of a social perspective. Where the performance of the social perspective in this study was used Corporate Social Responsibility (CSR) LPD based Tri Hita Karana.

The number of samples to be used is 59 LPD, sampling using simple random sampling method. After the questionnaire was collected again, a check was made for the feasibility of the questionnaire and tested for Validity and Reliability. Furthermore, data tabulation will be carried out according to the research variables. The tool that will be used for data analysis is SEM-PLS. Finally, the formulation of research results was carried out and then conclusions were drawn. 


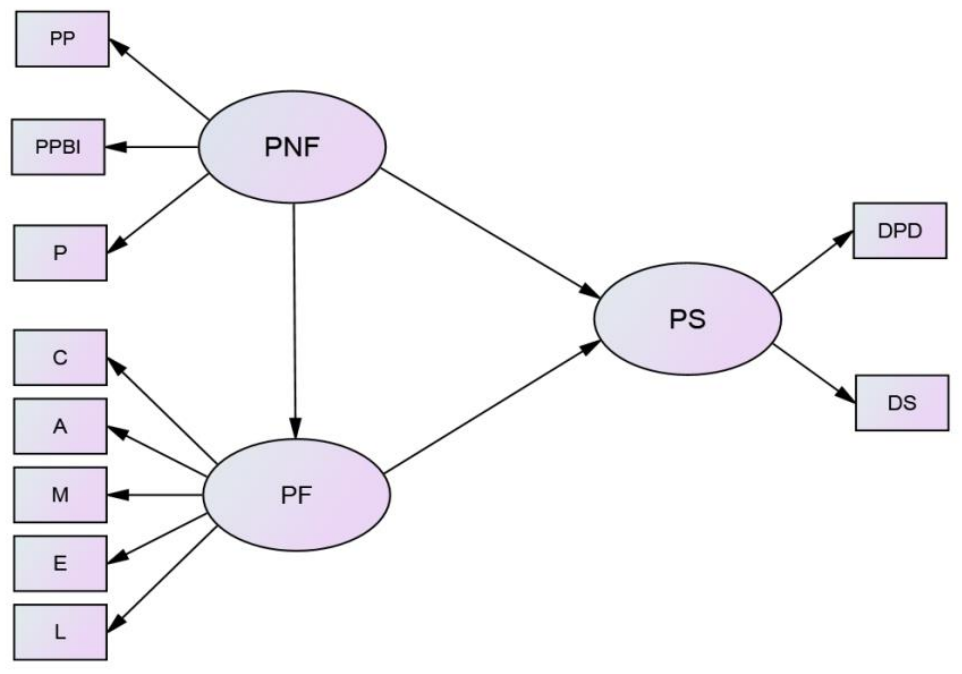

\section{Picture 1. Model : Sustainability Performance of Village Credit Institutions (LPD) in Buleleng Regency}

\section{Hasil dan pembahasan}

The output evaluation of the research model using the Smart-PLS program was carried out in two stages, evaluation of the measurement model (outer model) and evaluation of the structural model (inner model). Evaluation of the outer model measuring indicator variables can reflect or reflect the latent or construct variables. Inner model evaluation includes the real value of each path coefficient which states whether or not there is a real influence between constructs (latent variables) that are hypothesized. The output of the research model is presented in Table 1.

Table 1. Summary of Result Outer Model

\begin{tabular}{|c|c|c|}
\hline No & Criteria & Value of Research vs Standard Result \\
\hline 1 & $\begin{array}{l}\text { Converegent } \\
\text { Validity }\end{array}$ & $\begin{array}{l}\text { The inficator is said to be valid if it has a value of loading factor }>0,70 \text { and AVE has } \\
\text { a Value of }>0,5 \text {. All indicators meet Converegent Validity }\end{array}$ \\
\hline 2 & $\begin{array}{l}\text { Diskriminant } \\
\text { Validity }\end{array}$ & $\begin{array}{l}\text { Based on The value of cross loading and square root AVE, it can be concluded that } \\
\text { the measurements for each conctruct are declared valid according to the criteria of } \\
\text { discriminant validity, ie each indicator is correlated higher with each construct } \\
\text { compared to other constructs }\end{array}$ \\
\hline 3 & $\begin{array}{l}\text { Realibility } \\
\text { Construct }\end{array}$ & $\begin{array}{l}\text { See the output of cronbach's alpha. The criteria said to be reliable is the value of } \\
\text { composite reliability of Cronbach's Alpha }>0.7 \text {. Result : cronbach's alpha Financial } \\
\text { Perspective (0.880), Non Financial Perspective } 0.864) \text {, and PS ( } 0.736) \text {, all above } 0.7\end{array}$ \\
\hline
\end{tabular}

Table 2. Value Of Research Result And Inner Model Standard Evaluation Creteria

\begin{tabular}{|c|c|c|}
\hline No & Criteria & Value of Research Result vs Standard \\
\hline 1 & $\mathrm{R}^{2}$ & $\begin{array}{l}\text { The refrence value used to assess } \mathrm{R} 2 \text { is } 0.75,0.5 \text { and } 0.25 \text { which is } \\
\text { concluded that the model is strong, moderate and weak. Financial } \\
\text { Perspective Result (0.699) and Social Perspectives (0.681) }\end{array}$ \\
\hline 2 & Path Model Estimation & $\begin{array}{l}\text { The bootstrap result of path coeffcients obtained influence between } \\
\text { Non Financial Perspetive on Financial Perspective, Non Financial } \\
\text { Perspective on Social Perspective }<\text { Financial Perspectives on Social } \\
\text { Perspectives with t-statistics and their significance }>5 \%\end{array}$ \\
\hline 3 & $F^{2}$ effect size & $\begin{array}{l}\text { The refrence value used to assess } \mathrm{F} 2 \text { is } 0.02,0.15 \text { and } 0.35 \text { which is } \\
\text { interpreted that the latent variable predictors have small, medium, } \\
\text { and large influences. Financial perspective on social perspective } \\
0.282 \text {, Non financial perspective on social perspective } 0.092\end{array}$ \\
\hline
\end{tabular}


Table 3. Path Coefficient

\begin{tabular}{cccccc}
\hline & $\begin{array}{c}\text { Original } \\
\text { Sample (0) }\end{array}$ & $\begin{array}{c}\text { Sample } \\
\text { Mean (M) }\end{array}$ & $\begin{array}{c}\text { Standard Deviaton } \\
\text { (STDEV) }\end{array}$ & $\begin{array}{c}\text { T Statistics } \\
\text { (O/STDEV) }\end{array}$ & P values \\
\hline $\begin{array}{c}\text { Non Financial } \\
\text { Perspective -> }\end{array}$ & 0.836 & 0.840 & 0.040 & 20.790 & 0.000 \\
$\begin{array}{c}\text { Financial Perspective } \\
\text { Non Financial }\end{array}$ & 0.312 & 0.310 & 0.125 & 2.488 & 0.013 \\
$\begin{array}{c}\text { Perspective -> Social } \\
\text { Perspective }\end{array}$ & 0.547 & 0.551 & 0.120 & 4.550 & 0.000 \\
$\begin{array}{c}\text { Financial Perspective } \\
\text { > Social Perspective }\end{array}$ & & & & & \\
\hline
\end{tabular}

\section{Non-Financial Perspectives on Financial Perspectives}

Non-financial perspective variables have a positive and significant effect on financial perspective variables, as evidenced by the t-statistics value of 20.790 which is greater than the table value of 1.96 and the probability value ( $\mathrm{p}$ value) 0.000 is smaller than alpha $5 \%(0.05)$. The findings of this study indicate that to increase the success in sustained LPD performance it is necessary to see also from a nonfinancial perspective, so far most LPD only use the financial aspects. Financial measures are very important to measure the past, namely the results. However, non-financial actions are important decisions for LPD and are true in a world where change is faster and faster. Good sustainable performance must balance the financial and financial measures in order to achieve the objectives, mission and strategy set by an LPD.

\section{Non-Financial Perspective on Social Perspectives}

Non-financial perspective variables have a positive and significant effect on social perspective variables, as evidenced by a t-statistic value of 2.488 which is greater than the $t$ table value of 1.96 and a probability value of 0.013 smaller than the alpha value of $5 \%$. The findings of this study indicate that in order to maintain the sustainability of LPD the preparation of good strategic planning is not enough to just look at the non-financial perspective, but also to look at its social perspective, the social perspective in question is the implementation of social responsibility programs by the LPD. These demands are in accordance with current business practices that are not only focused on profit but also include social aspects of corporate social responsibility and accountability.

\section{Financial Perspective on Social Perspectives}

Financial perspective variables have a positive and significant effect on social perspectives, as evidenced by the t-statistics value of 4.550 which is greater than the t table value of 1.96 and the probability value ( $\mathrm{p}$ value) 0.000 is smaller than alpha $5 \%(0.05)$. The findings of this study indicate that in order to maintain the sustainability of the LPD, it is necessary to pay attention to the financial perspective, LPD to pay attention to the social aspects of corporate social responsibility. The financial perspective describes the financial success achieved and to formulate the financial goals to be achieved by the LPD, this financial perspective relates to social funds, where social funds reflect that the LPD should care about social aspects, the importance of social aspects, namely social responsibility in an LPD emphasizing the care of others to improve human welfare.

\section{Conclusion}

Based on the results of hypothesis testing shows that the performance of the non-financial perspective has a significant positive effect on the performance of the financial perspective of the LPD in Buleleng Regency. Second, the performance of non-financial perspectives has a significant positive effect on the performance of a social perspective based on Tri Hita Karana LPD in Buleleng Regency. The three financial perspective performance and non-financial perspective performance have a significant positive effect on the performance of a social perspective based on Tri Hita Karana LPD in Buleleng Regency.

The suggestion that researcher can convey is that each LPD should not only pay attention to the performance of the financial perspective, but must also pay attention to the condition of its non-financial perspective and social perspective in order to maintain the sustainable performance of the LPD. The recommendations that can be conveyed in this study should be that this model can be used to assess the continuous performance of LPD using the Balance Scorecard Method (BSC), which is viewed from a financial perspective, non-financial perspective and social perspective. 


\section{References}

Archie B. Carroll, "Understanding StakeholderThinking,” Business Ethics: A European Review,January 1997, 46-51. Also see Archie B. Carroll,"The Pyramid of Corporate Social Responsibility:Toward the Moral Management of OrganizationalStakeholders, "Business Horizons, July-August,1991, 39-48 (PDF) The Four Faces of Corporate Citizenship. Available from: https://www.researchgate.net/publication/227988859_The_Four_Faces_of_Corporate_Citizenship [accessed Sep 22 2018].

Adams, M., Thornton, B., \& Sepehri, M.2012. The impact of the pursuit of sustainability on the financial performance of the firm. Journal of Sustainability and Green Business,1.Retrieved from http://www.aabri.com/manuscripts/10706.pdf

Aggarwal, Priyanka. 2013. Impact of Sustainability Performance of Company on its Financial Performance: A Study of Listed Indian Companies. Global Journal of Management and Business Research Finance Vol. 13 Issue 11 Version 1.0. Online ISSN : 2249-4588 \& Print ISSN : 0975-5853. University of Delhi, India.

Ameer, R., \& Othman, R.2012.Sustainability Practices and Corporate Financial Performance: A Study Based on the Top Global Corporations. Journal of Business Ethics,108 (1), 61-79.Author, A.A. (Tahun Terbit). Judul Artikel. Nama Jurnal, Volume(Nomor), pp.-pp. DOI:XX.XXX atau Diakses dari http://xx

Budiasni, Novi. 2016. Penerapan Corporate Social Responsibility (CSR) pada Lembaga Keuangan Perkreditan Desa (Lpd) Berbasis Kearifan Lokal Di Bali. Tesis. Pascasarjana Universitas Pendidikan Nasional, Denpasar, Bali.

Bulelengkab.admin. Dua Puluh Tujuh LPD di Buleleng Macet, Lima Puluh Lima Desa Pakraman di Bali Belum Punya LPD. https://bulelengkab.go.id/detail/berita/dua-puluh-tujuh-lpd-di-buleleng macet-limapuluh-lima-desa-pakraman-di-bali-belum-punya-lpd-33. Diakses tanggal 3 Juni 2017

Clarkson, Peter M, et.al. 2007. Revisiting The Relation Between Environmental Performance and Environmental Disclosure: An Empirical Analysis. Accounting, Organizations and Society: Elsevier Journal.

De Klerk,M.,\& de Villiers,C.2012. The value relevance of corporate responsibility reporting: South Africa evidence. Meditari Accountancy Research, 20(1), 2-2.

Eccles,R.G.,Ioannou,I.,\& Serafeim,G.(2012).The impact of a corporate culture of sustainability on corporate behavior and performance (No. w17950). National Bureau of Economic Research.

Ghozali.Imam. 2007. Manajemen Risiko Perbankan. Semarang : BPUNDIP

Greenwald,C.2010. ESG and Earnings Performance. Thomson Reuters. Retrieved fromhttp://thomsonreuters.com/content/financial/pdf/news content/esg earnings peformance.p $\underline{\mathrm{df}}$

Guidry,R.P.,\&Patten,D.M.2010. Market reactions to the first-time issuance of corporate sustainability reports: Evidence that quality matters. Sustainability Accounting, Management and Policy Journal, 1(1), 33-50

Humphrey, J. E., Lee, D. D., \& Shen,Y.2012. The independent effects of environmental,social and governance initiatives on the performance of UK firms. Australian Journal of Management, 37 (2), 135-151.

Jones,S.2005.Notes of the University of Sydney Pacioli Society. Abacus, 41(2), 211-216.

Juliartana, I Wayan. LPD Motivator Pembangunan Desa .http://www.gianyarkab.go.id/?p=7381. Diakses tanggal 1 Juni 2017. 
Khaveh,A.,Nikhasemi,S.R.,Haque,A.,\& Yousefi, A.2012.Voluntary Sustainability Disclosure, Revenue, and Shareholders Wealth A Perspective from Singaporean Companies. Business Management Dynamics,1(9), 06-12.

Lako A. 2011. Dekonstruksi CSR dan Reformasi Paradigma Bisnis dan Akuntansi. Jakarta. Erlangga.

Lopez, M.V., Garcia, A., \& Rodriguez, L.2007.Sustainable development and corporate performance: A study based on the Dow Jones Sustainability Index. Journal of Business Ethics,75 (3), 285-300.

Perbawa, Sukawati Lanang P. LPD dan BPD Bali Penunjang Utama Perekonomian. http://buserkriminal.com/?p=5941. Diakses tanggal 5 Juni 2017.

Schadewitz, H., \& Niskala, M.2010. Communication via responsibility reporting and its effect on firm value in Finland. Corporate Social Responsibility and Environmental Management, 17(2), 96-106.

Van de Velde, E., Vermeir, W., \& Corten, F. 2005. Corporate social responsibility and financial performance. Corporate Governance, 5(3), 129-138.

Venanzi, D. 2012. Social Ratings and Financial Performance: An Instrumental Approach. Available at SSRN 2188859. 